\author{
Anzhelina Yaneva \\ ORCID: 0000-0002-7161-9156 \\ Emil Prokopov \\ ORCID: 0000-0003-2103-2223 \\ Uniwersytet Sofijski im. św. Klimenta z Ochrydy \\ Wydział Sportu
}

\title{
Мотивы включения студентов Софийского университета в волонтерские деятельности
}

\author{
Reasons for including Sofia University students \\ in voluntary activities
}

https://doi.org/10.34739/sn.2019.19.02

\begin{abstract}
Резюме: Исследование изучает мотивы студентов, обуславливающие включение или невключение в волонтерские деятельности. Проведено анонимное онлайн анкетирование среди занимающихся спортом студентов Софийского университета. Были заданы вопросы с открытыми и закрытыми ответами. Статья представляет отношение и мотивы студентов по включению в волонтерские деятельности. Результаты исследования поднимают проблемы, над которыми надо работать для изменения отношения занимающихся спортом студентов к участию в волонтерской деятельности в спорте.
\end{abstract}

Ключевые слова: волонтерство, спорт, студенты, мотивы

Abstract: The paper explores the motives of students included and not included in volunteer activities. An online anonymous survey was conducted among sports students at Sofia University, with questions allowing open and closed answers. The article presents students' attitudes and motivations to engage in volunteer activities. The results of the survey highlight the issues that need to be addressed to sportspeople, changing their attitudes towards sports and volunteer activities in sports.

Keywords: volunteering, sport, students, motivations

Волонтерство является важным аспектом активного гражданского участия. Оно создает социальный капитал, помогает социальному сближению и солидарности, предоставляет обществу ценные экономические пользы и возможность отдельным личностям реализовать свой потенциал. [ Становище на ЕИСК] 
Волонтерство «относится ко всем видам добровольческой деятельности, которые являются выражением свободной воли, выбора и мотивации данного лица и не имеют финансовой выгоды». [Ролята на доброволческите дейности, 2011]

Ввиду сегодняшнего кризиса в Европе, демографских изменений и связанными с ними трудностями, важно признать ключевое значение волонтерства для отдельных лиц как фактор, который улучшает приобщение, повышает личностную ответственность и создание навыков и сетей. Волонтерство, однако, должно быть разграничено от оплачиваемого труда и никаким образом не должно его замещать.

История волонтерства в Европе различается в разных державах. В некоторых из них существуют многолетние традиции в данной области, а в других - волонтерский сектор все еще слабо развит или вообще не существует. Исследования Евробарометра за 2007 г. показывают, что каждый третий европеец участвует в волонтерской деятельности. Некоторые исчисления определяют количество волонтеров в ЕС в размере от 92 до 94 млн. взрослых (23\% европейцев старше 15-ти лет). В последнее десятилетие наблюдается общее увеличение количества активных волонтеров и волонтерских организаций в Европейском союзе. [ec.europa.eu/commfrontoffice/publicopinion, 2019]

В Болгарии все больше волонтеров занимаются заступничеством, организуют компании, связанные с различными общественными целями, экологией, деятельностями, связанными с охранной окружающей среды. Волонтерство распространено по всему миру, особенно в социальной сфере при оказании помощи социально слабым людям и людям в бедственном положении. Волонтерство испытывает на себе сильное влияние истории, политики и культуры данной общности или государства. Со своей 140-летней историей Болгарский Красный крест является самой большой волонтерской организацией в Болгарии, которая имеет реальную сеть волонтеров по всей стране. В Болгарии волонтерских организаций становится все больше. Они представляют и распространяют ценности волонтерства и работают в направлении признания добровольческого труда в национальных масштабах.

В отличие от других европейских стран в Болгарии волонтерство не так развито в сферах образования и здравоохранения, и не поддерживается в такой степени в учебных и медицинских заведениях. Последние несколько лет в учебных заведениях молодым людям предоставляется возможность путешествовать за границу с целью 
участия в волонтерских проектах по европейской программе «Еразм+». Эти проекты дают участникам возможность познакомиться с культурой различных народов.

В последние годы волонтерство развивается в спорте, в качестве основного звена в организации спортивных мероприятий - состязаний и турниров различного уровня, включительно Мировых, Европейских и Олимпийских чемпионатов. Волонтерство в спорте наиболее развито В организации подготовки $и$ участия лиц с ограниченными возможностями - слепых, глухих, с физическими и умственными отклонениями.

Исследователь Туманова [2009] рассматривает проблему организации и проведения Олимпийских игр и роли волонтера в них, его развитие в историческом аспекте, сложный процесс воспитания в волонтерстве, мотивация, руководство и специализированное обучение.

Этот же автор исследует мнение студентов Софийского университета "Св. Кл. Охридски", занимающихся плаванием, на предмет их желания участвовать в качестве партнера в процессе обучения для людей с умственными отклонениями. Ответы показали, что большая часть из них присоединилась бы к этой инициативе. Более 70\% считают, что это бы помогло улучшению социализации и интеграции в общество и увеличит интерес к людям с ограниченными возможностями. Почти 90\% считают, что это поможет повысить мораль и гражданскую позицию молодого человека. [Туманова, 2012]

Волонтер - это человек, который по собстевенному желанию занимается альтруистичной деятельностью с целью улучшения качества жизни, что приносит чувство удовлетворения без финансовой выгоды.

Волонтерство является человеческой потребностью, которая приносит удовлетворение. Это образ мышления, который учит сопричастности и доброте, помогает получить знания и умения и совершенствоваться в течении всей жизни. Чаще всего наградой за усилия волонтеров является доброе слово, признание и похвала со стороны окружающих людей, волонтеров и организаторов.

Волонтерство развивает чувство ответственности, солидарности, принадлежности, оптимизма, которые являются характерными качествами спортсменов. Именно эти качества, сочетанные с познаниями и умениями в различных спортивных дисциплинах, дают возможность включиться в волонтерство в спортивной сфере. 
В связи с этим мы провели анкетирование среди занимающихся спортом студентов Университета о возможностях и их мотивах присоединения к волонтерским деятельностям во время их обучения.

Цель исследования изучить мнения студентов Софийского университета относительно их мотивов участия в волонтерских деятельностях, связанных с подготовкой и организацией спортивных мероприятий.

Задача исследования анализировать ответы, проведенной онлайн анкеты среди студентов СУ.

Были анкетированы 230 студентов Софийского университета „Св. Климент Охридски“, занимающихся определенным видом спорта. И только 205 респондентов ответили на все вопросы.

Возрастной диапазон исследуемых студентов варьирует от 19 до 24 лет. Из ответов анкетируемых следует, что 70 \% из них до сих пор не были волонтерами, а из тех, кто были, 62\% были больше двух раз.

На вопрос «Если вы были волонтером, откуда пришло приглашение?» студенты отвечают, что их друзья являются основным источником информации (47\%).

На вопрос «Если вы до сих пор были волонтером, каково ваше отношение?», 65\% респондентов имеют положительное отношение и включились бы в качестве волонтеров снова. Наблюдается низкий процент респондентов с отрицательным мнением - 8\% и тех, кто не может определиться - 24\%.

Из ответов тех, кто до сих пор не был волонтером следует, что 70\% анкетируемых твердят, что хотели бы стать волонтерами, если деятельность их заинтересует и у них будет достаточно времени (84\%), но 5\% согласны включиться, только если будут иметь выгоду. Радует тот факт, что только 4\% сообщают, что волонтерство не для них, но и не стоит пренебрегать мнением 12\% анкетированных, которые до сих пор не задумывались над этим вопросом. Эта информация показывает, что существует возможность повлиять на мнение студентов и преподаватель по спорту мог бы поставить вопрос перед колеблющимися студентами.

Рисунок 1. Если вы до сих пор не были волонтером, хотели бы вы когда-нибудь присоединиться? Из студентов, участвовавших в волонтерской деятельности, большинство участвовали в социальной сфере (37\%). Большая часть из них были волонтерами Болгарского красного креста (30\%). Выполняли различные благотворительные работы, связанные с благотворительной кухней, ярмарками, 
изготовлением сувениров, выгуливанием собак и заботой о детях с ограниченными возможностями (Рис. 1).

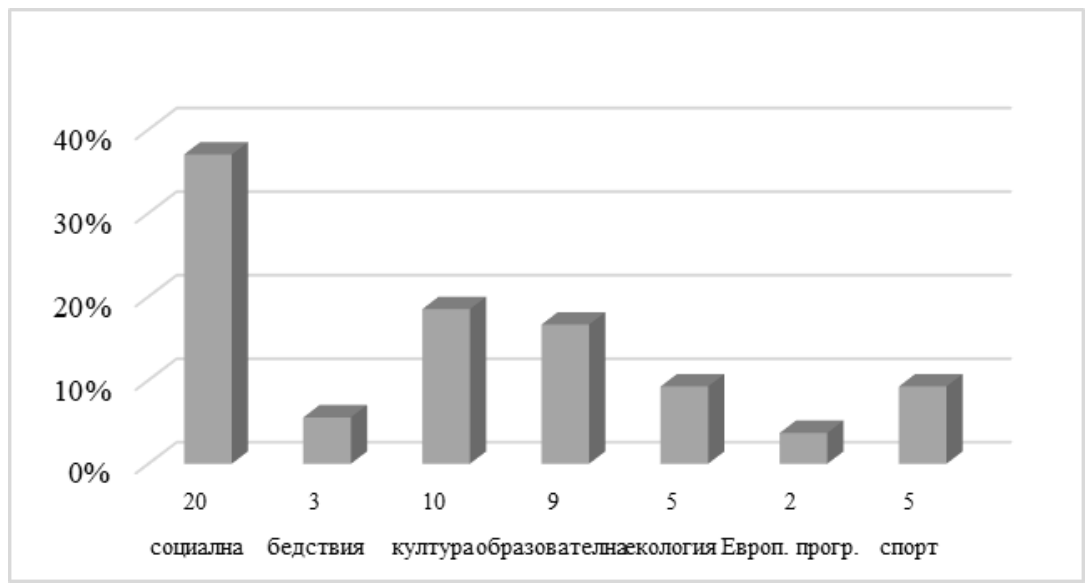

Рисунок 1. Сферы волонтерской деятельности

Меньше студентов участвовали в благотворительных деятельностях в образовательной и культурной сферах, но все же сравнительно больше, чем в других сферах как бедствия, экология, спорт. Европейские программы в основном присутствуют в образовательной сфере, в качестве идеи продвижения волонтерства. Студенты, участвовавшие в волонтерских деятельностях, связанных со спортом, являются студентами представительных команд Университета, т.е. имеющими спортивно-состязательные умения и познания.

В следующей группе вопросов выясняются причины и возможности включения в волонтерские деятельности. Причины, указанные студентами, в большой степени объясняют их мотивы включения в волонтерскую деятельность. Основными причинами (88\%) являются возможность помочь и быть полезным, получить новый опыт, знания и возможность общения с новыми людьми, создание контактов.

С уверенностью включились бы в волонтерскую деятельность 34\% анкетированных студентов Софийского университета, но 59\% включились бы в зависимости от события, т.е. если мероприятие им понравится или принесет дивиденды. 
Это возможность для преподавателей по спорту предоставить студентам больше информации о различных по виду спортивных событиях и пользах для них от приобретения опыта, социальных контактов, языкового общения, усовершенствование спортивнотехнической стороны их подготовки и как в большинстве кампаний получение диплома или сувенира.

То, что могло бы их мотивировать участвовать в деятельностях Университета, это положительное отражение в будущем или привилегия в Университете: 47\% - «Удостоверение или подтверждение, которое будет включено в мое CV в будущем», 19\% - «Бесплатный доступ и участие в деятельностях, организованных в Университете», 14\% «Некоторые привилегии по отношению преимущества при заявлении мероприятий с ограниченным количеством участников, определенные скидки за участие в платных мероприятиях (например: экскурсии, представления и т.д.)», 13\% - «Признание кредитов или запись в дипломе о высшем образовании». Больше $15 \%$ указывают все выше перечисленные причины.

Последний вопрос ставит напрямую проблему волонтерства в спортивных деятельностях и возможность участия. (Рис. 2) Данные в большой степени повторяют ответы на вопрос «Если бы у вас была возможность, включились ли бы вы в качестве волонтера в деятельность или мероприятие, организованное вашим университетом?». Зависит от мероприятия, отмечают 59\% опрошенных, но здесь студенты более осторожны, так только 12\% уверены, что будут участвовать, $13 \%$ - не желают принимать участие, а 16\% - не задумывались об этом. Эта осторожность и страх участвовать объясняется тем фактом, что многие студенты не являются активными спортсменами. Большинство из них начали практиковать данный вид спорта только в университете, а большинство опрошенных студентов являются первокурсниками или второкурсниками.

Чаще всего мотивы, которые высказывают студенты, желающие включиться в качестве волонтеров в спортивные события, следующие: знакомства и новые контакты, желание помочь и быть полезным, включительно поддержка имиджа Университета, бесплатный доступ к деятельностям, организованых университетом, привилегии при заявке мероприятий, практика и изучение иностранного языка и др. 


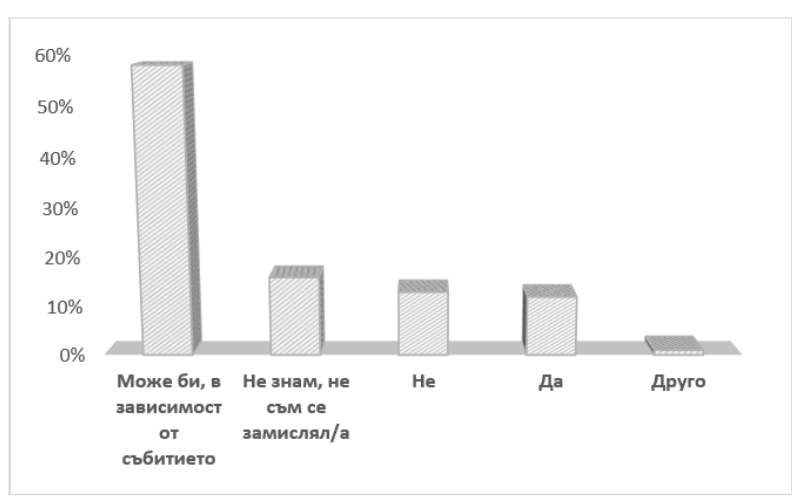

Рисунок 2. Участвовали ли вы бы в качестве волонтера в спортивном событии или конференции, организованной Университетом?

Проведенное исследование показывает, что есть возможность развития и увеличения волонтерской деятельностью среди молодежи и конкретно студентов. Результаты фокусируют внимание на возможностях, над которыми необходимо работать, а именно:

- Преподаватели должны информировать и включать студентов в различные спортивные деятельности Университета.

- Включение студентов не только из представительных команд, но из учебных групп, в процесс обучения в качестве помощника преподавателя. Студентам предоставляется возможность познакомиться с методикой и организацией обучения в данном виде спорта, когда они временно перенимают роль тренера.

- Знакомство с правилами состязания и совместные наблюдения во время состязаний.

- Предоставление возможности участвовать в волонтерских деятельностях в спорте и в спортивных событиях.

- Постановка задач для изучения некоторых проблем, связанных с организацией спортивных событий и место волонтера и волонтерских работ в организации этих событий.

Из всего сказанного здесь и положительного отношения студентов можно обобщить, что существуют возможности развития и увеличения волонтерской деятельностью в сфере спорта в условиях университетского обучения вкупе с активной работой преподавателя по спорту в Софийском университете „Св. Климент Охридски“. 


\section{Literatura [Литература]}

Stanovishche na YEISK, (2012) [Становище на ЕИСК, (2012)] http://www.knsb-bg.org/pdf/479/pdf, [11.03.2019].

Tumanova B., (2009), Rol' volonterstva v organizatsii Olimpiyskikh igr, Godishnik SU, t. 85, UIP. [Туманова Б., (2009), Роль волонтерства в организации Олимпийских игр, Годишник СУ, т. 85, УИП].

Tumanova B., (2012), Optimizatsiya uchebnogo protsessa po plavaniyu u lyudey s ogranichennymi intellektual'nymi vozmozhnostyami s uchastiyem partnerov bezinvalidnosti, [v:] Sovremennyye tendentsii fizicheskogovospitaniya i sporta, UIP, Sofiya. [Туманова Б., (2012), Оптимизация учебного прочесса по плаванию у людей с ограниченными интеллектуальными возможностями с участием партнеров без инвалидности, [в:] Современные тенденции физического воспитания и спорта, УИП, София].

www.ec.europa.eu/commfrontoffice/publicopinion, (2019), [11.03.2019].

Zaklyucheniya na YES, Rolyata na dobrovolcheskite deynosti $v$ sotsialnata politika, 2011. [Заключения на ЕC, Ролята на доброволческите дейности в социалната политика, (2011).] 